\title{
Equation of Arithmetic Mean Deviation of Roughness Profile
}

\author{
Leonid Lesovoy, Fedir Matiko, Bohdan Chaban* \\ Lviv Polytechnic National University, 12 Stepana Bandery St., Lviv, 79013, Ukraine
}

Received: October 17, 2018. Revised: March 18, 2019. Accepted: August 27, 2019.

(c) 2019 The Authors. Published by Lviv Polytechnic National University.

\begin{abstract}
In order to improve the accuracy of gas flowrate measurement by means of the differential pressure flowmeters, it is necessary to apply equations for determination of coefficients of gas flow equation, which would provide the lowest total relative expanded uncertainty of calculation, and to increase the accuracy of input values measurement in real time. One of these values is the arithmetic mean deviation of roughness profile of pipe internal surface. The equation for calculating the arithmetic mean deviation of roughness profile of pipe internal surface in real time was obtained. The equation for calculating the total relative expanded uncertainty of measurement result of arithmetic mean deviation of roughness profile of pipe internal surface in real time and components of this uncertainty were obtained.
\end{abstract}

Keywords: gas flowrate; roughness; measurement; uncertainty; pipeline parameters.

\section{Introduction}

Differential pressure method is applied for gas flowrate measurement. The requirements to the differential pressure flowmeters are presented in ISO 5167-1,2,3,4:2003 [1]-[4] and AGA 3-1,2:2003 [5], [6] standards.

Mass gas flowrate according to the differential pressure method is determined by the equation [1]

$$
q_{m}=\frac{C}{\sqrt{1-\beta^{4}}} \varepsilon \frac{\pi}{4} d^{2} \sqrt{2 \rho \Delta p}
$$

where $C$ is discharge coefficient; $\beta$ is diameter ratio of primary device throat; $\varepsilon$ is expansion factor of gas; $d$ is diameter of primary device throat under working conditions; $\rho$ is density of gas under working conditions (at absolute gas pressure $p$ and thermodynamic temperature of gas $T$ ); $\Delta p$ is differential pressure across the primary device.

Discharge coefficient is one of basic coefficients of the gas flowrate equation. Each primary device is described by its discharge coefficient. The equations of discharge coefficients are presented in:

- ISO 5167-2:2003 [2] for orifice plate;

- ISO 5167-3:2003 [3] for nozzle, long radius nozzles and Venturi nozzle;

- ISO 5167-4:2003 [4] for Venturi tubes.

Discharge coefficient of each primary device is determined in a certain range of relative roughness of pipe internal surface, which depends on arithmetic mean deviation of roughness profile $R a$ of pipe internal surface and upstream internal pipe diameter $D$ under working conditions.

${ }^{*}$ Corresponding author. Email address: techinfoflow@yahoo.co.uk

This paper should be cited as: L. Lesovoy, F. Matiko, B. Chaban. Equation of arithmetic mean deviation of roughness profile. Energy Engineering and Control Systems, 2019, Vol. 5, No. 2, pp. 81 - 88. https://doi.org/10.23939/jeecs2019.02.081 
The arithmetic mean deviation of the profile $R a$ is the mean value of the absolute value of the profile departure $y$ within the reference length $l$ (Fig.1).

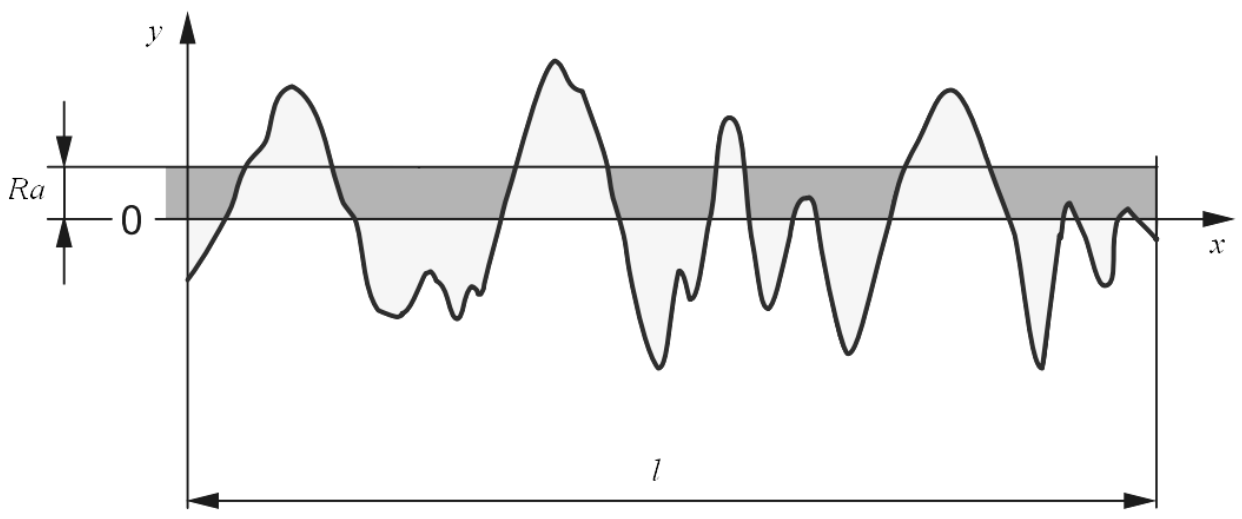

Fig. 1. The arithmetic mean deviation of the profile.

The arithmetic mean deviation of the profile $R a$ is determined by equation [7]

$$
R a=\frac{1}{l} \int_{0}^{l}|y(x)| d x=\frac{1}{n} \sum_{i=1}^{n}\left|y_{i}\right|,
$$

where $n$ is number of measurements.

Relative roughness of pipe internal surface is determined as $10^{4} \frac{R a}{D}$. Allowable values of $10^{4} \frac{R a}{D}$ depend on the type of the primary device and are presented in:

- Table 1 and Table 2 of ISO 5167-2:2003 [2] for orifice plate;

Table 1. Maximum value of relative roughness.

\begin{tabular}{|c|c|c|c|c|c|c|c|c|c|}
\hline \multirow{2}{*}{$\beta$} & \multicolumn{9}{|c|}{$\operatorname{Re}_{D}$} \\
\cline { 2 - 10 } & $\leq 10^{4}$ & $3 \cdot 10^{4}$ & $10^{5}$ & $3 \cdot 10^{5}$ & $10^{6}$ & $3 \cdot 10^{6}$ & $10^{7}$ & $3 \cdot 10^{7}$ & $10^{8}$ \\
\hline$\leq 0.20$ & 15 & 15 & 15 & 15 & 15 & 15 & 15 & 15 & 15 \\
\hline 0.30 & 15 & 15 & 15 & 15 & 15 & 15 & 15 & 14 & 13 \\
\hline 0.40 & 15 & 15 & 10 & 7.2 & 5.2 & 4.1 & 3.5 & 3.1 & 2.7 \\
\hline 0.50 & 11 & 7.7 & 4.9 & 3.3 & 2.2 & 1.6 & 1.3 & 1.1 & 0.9 \\
\hline 0.60 & 5.6 & 4.0 & 2.5 & 1.6 & 1.0 & 0.7 & 0.6 & 0.5 & 0.4 \\
\hline$\geq 0.65$ & 4.2 & 3.0 & 1.9 & 1.2 & 0.8 & 0.6 & 0.4 & 0.3 & 0.3 \\
\hline
\end{tabular}

Table 2. Minimum value of relative roughness.

\begin{tabular}{|c|c|c|c|c|}
\hline \multirow{2}{*}{$\beta$} & \multicolumn{4}{|c|}{$\operatorname{Re}_{D}$} \\
\cline { 2 - 5 } & $\leq 3 \cdot 10^{6}$ & $10^{7}$ & $3 \cdot 10^{7}$ & $10^{8}$ \\
\hline$\leq 0.50$ & 0.0 & 0.0 & 0.0 & 0.0 \\
\hline 0.60 & 0.0 & 0.0 & 0.003 & 0.004 \\
\hline$\geq 0.65$ & 0.0 & 0.013 & 0.016 & 0.012 \\
\hline
\end{tabular}

The Reynolds number $\operatorname{Re}_{D}$ in Table 1 and Table 2 is determined by equation [1]

$$
\operatorname{Re}_{D}=\frac{4 q_{m}}{\pi \mu D}
$$

where $\mu$ is gas dynamic viscosity under working conditions. 
- Table 3 of ISO 5167-3:2003 [3] for ISA 1932 nozzles;

Table 3. Upper limits of relative roughness of the upstream pipe for ISA 1932 nozzles.

\begin{tabular}{|c|c|c|c|c|c|c|c|c|c|c|c|c|c|}
\hline$\beta$ & $\leq 0.35$ & 0.36 & 0.38 & 0.40 & 0.42 & 0.44 & 0.46 & 0.48 & 0.50 & 0.60 & 0.70 & 0.77 & 0.80 \\
\hline $10^{4} \frac{R a}{D}$ & 8.0 & 5.9 & 4.3 & 3.4 & 2.8 & 2.4 & 2.1 & 1.9 & 1.8 & 1.4 & 1.3 & 1.2 & 1.2 \\
\hline
\end{tabular}

- according to ISO 5167-3:2003 [3] for long radius nozzles the upper limits of relative roughness $10^{4} \frac{R a}{D}=3,2$ in the upstream pipe work;

- Table 4 of ISO 5167-3:2003 [3] for Venturi nozzles;

Table 4. Upper limits of relative roughness of the upstream pipe for Venturi nozzles.

\begin{tabular}{|c|c|c|c|c|c|c|c|c|c|c|c|c|}
\hline$\beta$ & $\leq 0.35$ & 0.36 & 0.38 & 0.40 & 0.42 & 0.44 & 0.46 & 0.48 & 0.50 & 0.60 & 0.70 & 0.775 \\
\hline $10^{4} \frac{R a}{D}$ & 8.0 & 5.9 & 4.3 & 3.4 & 2.8 & 2.4 & 2.1 & 1.9 & 1.8 & 1.4 & 1.3 & 1.2 \\
\hline
\end{tabular}

- according to ISO 5167-4:2003 [4] for each type of Venturi tube the upper limits of relative roughness $10^{4} \frac{R a}{D}=3,2$ on a length at least equal to $2 D$ measured from the upstream end of the entrance cylinder of the Venturi tube.

Differential pressure method cannot be applied when the relative roughness of pipe internal surface does not conform to the maximum and minimum allowable values described above on distance $L$ upstream to primary device ( $L \leq 10 D$ [2], [3] for orifice plate, any nozzle and $L \leq 2 D$ [4] for each type of Venturi tube) or to the first local resistance. Therefore, measurement of arithmetic mean deviation of roughness profile of pipe internal surface in real time is an important problem to be solved.

\section{Definition of arithmetic mean deviation of the roughness profile of pipe internal surface in real time}

For definition of arithmetic mean deviation of the roughness profile $R a$ of pipe internal surface in real time the following equations are applied:

- system of differential equations [8]

$$
\left\{\begin{array}{c}
\frac{d p}{\rho}+\frac{\lambda v^{2}}{2 D} d x=0 \\
\frac{d m}{d \tau}=q_{m}=\rho v F=\text { const }
\end{array}\right.
$$

where $d p$ is the variation of the gas pressure across elementary pipe section $d x$ upstream of primary device; $\lambda$ is the hydraulic resistance coefficient of friction of gas on the internal surface of pipe; $v$ is the linear velocity of gas in pipe; $d m$ is the variation of gas mass during the period of time $d \tau ; F$ is the cross sectional area of pipe;

- Colebrook-White equation [9]

$$
\frac{k_{S}}{D}=\left(3.71 \cdot 10^{-\frac{1}{2 \cdot \sqrt{\lambda}}}-\frac{9.34}{\operatorname{Re}_{D} \sqrt{\lambda}}\right),
$$

where $k_{s}$ is equivalent roughness of the pipe internal surface. 
By solving the system of differential equations (3) we obtained the pressure distribution $p_{x}$ along the length $x$ of the pipe, which is determined by the equation

$$
p_{x}=\sqrt{p_{1}^{2}-\left(p_{1}^{2}-p^{2}\right) \frac{x}{L}}
$$

where $p_{1}$ is gas pressure at a distance $L$ before primary device; $\bar{\rho}$ is average value of gas density along the length of pipe, which is determined by the gas thermodynamic temperature $T$ and the average value of gas pressure $\bar{p}$ along the length of pipe.

Based on (5) the average value of gas pressure $\bar{p}$ along the length of pipe is determined by the equation

$$
\bar{p}=\frac{1}{L} \int_{0}^{L} \sqrt{p_{1}^{2}-\left(p_{1}^{2}-p^{2}\right) \frac{x}{L}} d x=\frac{2}{3}\left(p_{1}+\frac{p^{2}}{p_{1}+p}\right) .
$$

By replacing the value $p_{1}$ based on the measured value of differential pressure along the length of the pipe $\Delta p_{L}$ is defined by the equation

$$
p_{1}=p+\Delta p_{L}
$$

we obtain the equation for calculating the average value of gas pressure along the length of the pipe

$$
\bar{p}=\frac{2}{3} p\left(1+\tau_{L}+\frac{1}{2+\tau_{L}}\right)
$$

where

$$
\tau_{L}=\frac{\Delta p_{L}}{p}
$$

By substituting coefficient $\lambda$ in equation (4) and taking into account that [10]

$$
R a=\frac{k_{S}}{\pi},
$$

we obtain the equation for measurement of $R a$ in real time

$$
R a=\frac{D}{\pi}\left(3.71 \cdot 10^{-\mathrm{Re}_{D} \cdot A}-18.68 \cdot A\right),
$$

where $A$ is coefficient, which is defined by the equation

$$
A=\frac{\mu}{D\left(2+\tau_{L}\right)} \sqrt{\frac{L\left(\tau_{L}^{2}+3 \tau_{L}+3\right)}{6 \Delta p_{L} \bar{\rho} D}} .
$$

Considering (2), equation (10) can be written as

$$
R a=\frac{D}{\pi}\left(3.71 \cdot 10^{-\frac{4 q_{m} A}{\pi \mu D}}-18.68 \cdot A\right)
$$


3. Definition of total relative expanded uncertainty of measurement result of arithmetic mean deviation of roughness profile of pipe internal surface

According to (12) considering the equations (8) and (11) the value of $R a$ depends on the set of input values $X$

$$
X \in\left(\Delta p_{L}, L, p, D, \bar{\rho}, \mu, q_{m}\right)
$$

i. e.

$$
R a=f(X) .
$$

Total relative expanded uncertainty of measurement result of arithmetic mean deviation of roughness profile of pipe internal surface in real time is calculated by the equation [11], [12]

$$
U_{R a}^{*}=\sqrt{c_{\Delta p_{L}}^{* 2} U_{\Delta p_{L}}^{* 2}+c_{L}^{* 2} U_{L}^{* 2}+c_{p}^{* 2} U_{p}^{* 2}+c_{D}^{* 2} U_{D}^{* 2}+c_{\rho}^{* 2} U_{\rho}^{* 2}+c_{\mu}^{* 2} U_{\mu}^{* 2}+c_{q_{m}}^{* 2} U_{q_{m}}^{* 2}},
$$

where $c_{\Delta p_{L}}^{*}$ is the relative sensitivity coefficient of arithmetic mean deviation of roughness profile of pipe internal surface to the differential pressure between pressure of gas on distance $L$ upstream to primary device and pressure of gas inlet face of primary device; $c_{L}^{*}$ is the relative sensitivity coefficient of arithmetic mean deviation of roughness profile of pipe internal surface to the length of straight section $L$ of pipe; $c_{p}^{*}$ is the relative sensitivity coefficient of arithmetic mean deviation of roughness profile of pipe internal surface to the gas pressure at the inlet face of the primary device; $c_{D}^{*}$ is the relative sensitivity coefficient of arithmetic mean deviation of roughness profile of pipe internal surface to the upstream internal pipe diameter under working conditions; $c_{-}^{*}$ is the relative sensitivity coefficient of arithmetic mean deviation of roughness profile of pipe internal surface to the average value of gas density along the length of the pipe; $c_{\mu}^{*}$ is the relative sensitivity coefficient of arithmetic mean deviation of roughness profile of pipe internal surface to the gas dynamic viscosity under working conditions; $c_{q_{m}}^{*}$ is the relative sensitivity coefficient of arithmetic mean deviation of roughness profile of pipe internal surface to the mass gas flowrate; $U_{\Delta p_{L}}^{*}$ is the relative expanded uncertainty of measurement result of the differential pressure between pressure of gas on distance $L$ upstream to primary device and pressure of gas inlet face of primary device; $U_{L}^{*}$ is the relative expanded uncertainty of measurement result of the length of the straight section $L$ of pipe; $U_{p}^{*}$ is the relative expanded uncertainty of measurement result of the gas pressure at the inlet face of the primary device; $U_{D}^{*}$ is the relative expanded uncertainty of measurement result of the upstream internal pipe diameter under working conditions; $U_{\bar{\rho}}^{*}$ is the relative expanded uncertainty of measurement result of the average value of gas density along the length of the pipe; $U_{\mu}^{*}$ is the relative expanded uncertainty of measurement result of the gas dynamic viscosity under working conditions; $U_{q_{m}}^{*}$ is the relative expanded uncertainty of measurement result of the mass flowrate of gas.

\section{Definition of relative sensitivity coefficient of output value to input value}

The relative sensitivity coefficient of arithmetic mean deviation of roughness profile of pipe internal surface to parameter $i$ of $x_{i} \in X$ is determined by the equation [11]

$$
c_{x_{i}}^{*}=\frac{\partial R a}{\partial x_{i}} \frac{x_{i}}{R a} .
$$


From (16) the relative sensitivity coefficient of arithmetic mean deviation of roughness profile of pipe internal surface to the differential pressure between pressure of gas on distance $L$ upstream to primary device and pressure of gas inlet face of primary device is determined by the equation

$$
c_{\Delta p_{L}}^{*}=\frac{\partial R a}{\partial \Delta p_{L}} \frac{\Delta p_{L}}{R a} .
$$

Considering (2), (8), (11) and (12), equation (17) can be rewritten as

$$
c_{\Delta p_{L}}^{*}=-A_{c^{*}}\left[c_{\Delta p_{L}}^{* \bar{p}}-\frac{2\left(1+\tau_{L}\right)}{2+\tau_{L}}\right],
$$

where

$$
A_{c}=\frac{D A}{2 \pi R a}\left(3.71 \frac{10^{-\mathrm{Re} \cdot A}}{\ln 10} \mathrm{Re}+18.68\right) .
$$

The relative sensitivity coefficient of arithmetic mean deviation of roughness profile of pipe internal surface to the length of the straight section $L$ of pipe is determined by the equation

$$
c_{L}^{*}=\frac{\partial R a}{\partial L} \frac{L}{R a} .
$$

Considering (2), (11) and (12), equation (19) can be rewritten as

$$
c_{L}^{*}=-A_{c^{*}}
$$

The relative sensitivity coefficient of arithmetic mean deviation of roughness profile of pipe internal surface to the gas pressure at the inlet face of the primary device is determined by the equation

$$
c_{p}^{*}=\frac{\partial R a}{\partial p} \frac{p}{R a} .
$$

Considering (2), (8), (11) and (12), equation (21) can be rewritten as

$$
c_{p}^{*}=-A_{c^{*}}\left(c_{p}^{* \bar{p}}-\frac{2}{2+\tau_{L}}\right) \text {. }
$$

The relative sensitivity coefficient of arithmetic mean deviation of roughness profile of pipe internal surface to the upstream internal pipe diameter under working conditions is determined by the equation

$$
c_{D}^{*}=\frac{\partial R a}{\partial D} \frac{D}{R a}
$$

Considering (2), (11) and (12), equation (23) can be rewritten as

$$
c_{D}^{*}=1+5 A_{c^{*}} .
$$

The relative sensitivity coefficient of arithmetic mean deviation of roughness profile of pipe internal surface to the average value of gas density along the length of the pipe is determined by the equation

$$
c_{-}^{*}=\frac{\partial R a}{\partial \bar{\rho}} \frac{\bar{\rho}}{R a} .
$$


Considering (2), (11) and (12), equation (25) can be rewritten as

$$
c_{\bar{\rho}}^{*}=A_{c^{*}} .
$$

The relative sensitivity coefficient of arithmetic mean deviation of roughness profile of pipe internal surface to the gas dynamic viscosity under working conditions is determined by the equation

$$
c_{\mu}^{*}=\frac{\partial R a}{\partial \mu} \frac{\mu}{R a} .
$$

Considering (2), (11) and (12), equation (27) can be rewritten as

$$
c_{\mu}^{*}=-\frac{18.68 D A}{R a} .
$$

The relative sensitivity coefficient of arithmetic mean deviation of roughness profile of pipe internal surface to the mass flowrate of gas is determined by the equation

$$
c_{q_{m}}^{*}=\frac{\partial R a}{\partial q_{m}} \frac{q_{m}}{R a} .
$$

Considering (2), (11) and (12), equation (29) can be rewritten as

$$
c_{q_{m}}^{*}=-\frac{3.71 \operatorname{Re} D A}{R a \ln 10} 10^{-\mathrm{Re} \cdot A} .
$$

Considering (18), (20), (22), (24), (26), (28) and (30), equation (15) takes the form

$$
\begin{aligned}
& U_{R a}^{*}=\left\{A_{c^{*}}^{2}\left[c_{\Delta p_{L}}^{* \bar{p}}-\frac{2\left(1+\tau_{L}\right)}{2+\tau_{L}}\right]^{2} U_{\Delta p_{L}}^{* 2}+A_{c^{*}}^{2} U_{L}^{*_{2}}+A_{c^{*}}^{2}\left(c_{p}^{* \bar{p}}-\frac{2}{2+\tau_{L}}\right)^{2} U_{p}^{* 2}+\right. \\
& \left.+\left(1+5 A_{c^{*}}\right)^{2} U_{D}^{* 2}+A_{c^{*}}^{2} U_{\bar{\rho}_{L}}^{* 2}+\left(\frac{18.68 D A}{R a}\right)^{2} U_{\mu}^{*_{2}}+\left(\frac{3.71 \operatorname{Re} D A}{\operatorname{Ra} \ln 10} 10^{-\mathrm{Re} \cdot A}\right)^{2} U_{q_{m}}^{*_{2}}\right\}^{0,5} .
\end{aligned}
$$

\section{Conclusion}

The new equation for calculating the arithmetic mean deviation of roughness profile of pipe internal surface in real time was obtained in order to solve the problems associated with the gas flowrate measurement by means of the differential pressure flowmeters. The input values which affect on measurement the arithmetic mean deviation of roughness profile of the inner surface of the measuring pipeline in real time are determined. The equations for calculating the relative sensitivity coefficient of the arithmetic mean deviation of roughness profile of pipe internal surface to the input values were obtained. The equation of total relative expanded uncertainty of measurement result of arithmetic mean deviation of roughness profile of pipe internal surface in real time and the equations for calculating the components this total uncertainty were obtained.

\section{References}

[1] Measurement of fluid flow by means of pressure differential devices inserted in circular cross-section conduits running full - Part 1: General principles and requirements: ISO 5167-1:2003. - Geneva (Switzerland): International Organization for Standardization (ISO), 2007. - 40 pages. (International standard).

[2] Measurement of fluid flow by means of pressure differential devices inserted in circular cross-section conduits running full - Part 2: Orifice plates: ISO 5167-2:2003. - Geneva (Switzerland): International Organization for Standardization (ISO), 2007. - 54 pages. (International standard). 
[3] Measurement of fluid flow by means of pressure differential devices inserted in circular cross-section conduits running full - Part 3: Nozzles and Venturi nozzles: ISO 5167-3:2003. - Geneva (Switzerland): International Organization for Standardization (ISO), 2007. - 30 pages. (International standard).

[4] Measurement of fluid flow by means of pressure differential devices inserted in circular cross-section conduits running full - Part 4: Venturi tubes: ISO 5167-4:2003. - Geneva (Switzerland): International Organization for Standardization (ISO), 2007. - 24 pages. (International standard).

[5] Orifice metering of natural gas and other related hydrocarbon fluids - Part 1: General equations and uncertainty guidelines: AGA Report No.3. - Washington (USA): American Gas Association and American Petroleum Institute (AGA), 2003. - 54 pages. (International standard).

[6] Orifice metering of natural gas and other related hydrocarbon fluids - Part 2: Specification and installation requirements: AGA Report No.3. - Washington (USA): American Gas Association and American Petroleum Institute (AGA), 2003 - 74 pages. (International standard).

[7] Geometrical Product Specifications (GPS) - Surface texture: Profile method - Terms, definitions and surface texture parameters: ISO 4287:1997. - Geneva (Switzerland): International Organization for Standardization (ISO), 1997. - 25 pages. (International standard).

[8] Chaban B., Lesovoi L. (2015). Definition of equivalent roughness of internal surface of a measuring pipeline. Proc. of 5th International Academic Conference EPECS 2015. Lviv, Ukraine, pp. 152-153.

[9] VDI/VDE 2040 Blatt 1:1991-01 Calculation principles for the measurements of fluid flow - Using orifice plates, nozzles and Venturi tubes Deviations and supplements to DIN 1952.

[10] Chaban B. (2015). Measurement of Roughness of Internal Surface of a Measuring Pipeline in Real Time for Standard Orifice Plates. Energy Engineering and Control Systems, Vol.1, No. 2, pp. 133-138.

[11] Measurement of fluid flow - Procedures for the evaluation of uncertainties: ISO 5168. - Geneva (Switzerland): International Organization for Standardization (ISO), 2005. - 66 pages. (International standard).

[12] Uncertainty of Measurement - Part 3: Guide to the Expression of Uncertainty in Measurement / Third edition - ISO/IEC Guide 98-3:2008 Geneva (Switzerland): International Organization for Standardization (ISO), 2008. - 120 pages.

\title{
Рівняння середнього арифметичного профілю шорсткості
}

\author{
Леонід Лесовой, Федір Матіко, Богдан Чабан \\ Національний університет «Львівська політехніка», вул. Степана Бандери 12, Львів, 79013, Украӥна
}

\section{Анотація}

Для підвищення точності вимірювання витрати газу за допомогою витратомірів змінного перепаду тиску необхідно застосувати залежності для визначення коефіцієнтів рівняння витрати газу, що забезпечать найменшу відносну сумарну розширену невизначеність розрахунку та збільшать точність вимірювання вхідних величин в реальному часі. Однією з таких величин $є$ середнє арифметичне відхилення профілю шорсткості внутрішньої поверхні трубопроводу. Отримано рівняння для розрахунку середнього арифметичного відхилення профілю шорсткості внутрішньої поверхні труби в реальному часі. Отримано рівняння для розрахунку відносної сумарної розширеної невизначеності результату вимірювання середнього арифметичного відхилення профілю шорсткості внутрішньої поверхні трубопроводу в реальному часі та складників цієї невизначеності.

Ключові слова: витрата газу; шорсткість; невизначеність; параметри трубопроводу. 